\title{
The assessment of water quality in river Molo water basin, Kenya
}

\author{
Emily B. Chebet ${ }^{1}$. Joshua K. Kibet ${ }^{1}$ (D) Damaris Mbui ${ }^{2}$
}

Received: 27 August 2018 / Accepted: 3 March 2020 / Published online: 14 March 2020

(c) The Author(s) 2020

\begin{abstract}
The monitoring of water quality for both domestic and commercial use is absolutely essential for policy formulation that affects both public and environmental health. This study investigates the quality of water of river Molo system which lies in the Kenyan Rift Valley. The river is considered a vital source of water for the residents and industrial activities in Nakuru and Baringo Counties. Six water samples were collected during the dry season of December 2017. Various physicochemical parameters were determined in situ by use of a portable $\mathrm{pH}$ meter. These parameters included $\mathrm{pH}$, temperature, electrical conductivity and total dissolved solids (TDS). Anions such as fluorides, sulfates, phosphates, nitrates, chlorides, carbonates and bicarbonates were determined using conventional methods such as titrimetry and (ultra-violet visible) UV-Vis techniques. The cations including sodium, potassium, calcium and magnesium were determined using flame photometry. The results showed that the water had $\mathrm{pH}$ values ranging from 7.90 to 9.66 units, temperature ranged from 14.02 to $31.5^{\circ} \mathrm{C}$, while electrical conductivity ranged from 181 to $1637 \mu \mathrm{S} / \mathrm{cm}$, TDS (69-823 mg/L), F (2.76-3.28 mg/L), sulfates (4.97-85.66 mg/L), phosphates $(0.13-11.06 \mathrm{mg} / \mathrm{L})$, nitrates $(1.73-6.16 \mathrm{mg} / \mathrm{L})$, chlorides $(38.5-69.4 \mathrm{mg} / \mathrm{L})$, carbonates $(18-148 \mathrm{mg} / \mathrm{L})$, bicarbonates $(54-384 \mathrm{mg} / \mathrm{L})$, sodium $(19-1800 \mathrm{mg} / \mathrm{L})$, potassium $(8.9-121 \mathrm{mg} / \mathrm{L})$, magnesium $(4.8-106.8 \mathrm{mg} / \mathrm{L})$ and calcium (13.4-77.4 mg/L). The $\mathrm{pH}$, temperature, fluorides and sodium were above the World Health Organization permissible limits for drinking water in $\mathrm{S} 4$ and $\mathrm{S} 5$. All the water samples fall under bicarbonate or freshwater zone. The sampling points can be classified into five water types: $\mathrm{Na}-\mathrm{Mg}-\mathrm{Ca}-\mathrm{HCO}_{3}, \mathrm{Na}-\mathrm{HCO}_{3}, \mathrm{Na}-\mathrm{Ca}-\mathrm{Mg}-\mathrm{HCO}_{3}-\mathrm{CO}_{3}, \mathrm{Na}$ and $\mathrm{Na}-\mathrm{Ca}-\mathrm{HCO}_{3}-\mathrm{CO}_{3}$. Chemical indices such as sodium adsorption ratio, magnesium hazard, percent sodium and permeability index are reported. Accordingly, the findings from this work indicate that the river Molo water in general is good for irrigation.
\end{abstract}

Keywords Flower farm effluents $\cdot$ Magnesium hazard $\cdot$ River Molo $\cdot$ Water contaminants

\section{Introduction}

There have been enhanced attempts aimed at developing water models that predict water quality regimes and forecast histories of intensive mineralization which influence groundwater systems, resulting in occurrence of different water classifications (Wang et al. 2014; Chau 2005). Studies such as the artificial neural network (ANN) model for suspended sediment forecasting in several time steps, soft computing methods such as adaptive neuro-fuzzy inference system (ANFIS) and AquaChem computational models have

Joshua K. Kibet

jkibet@egerton.ac.ke

1 Department of Chemistry, Egerton University, P.O Box 536 -20115, Egerton, Kenya

2 Department of Chemistry, University of Nairobi, GPO, P.O. Box 30197, Nairobi, Kenya become necessary in investigating water quality in addition to the traditional experimental methods (Wang et al. 2014; Wu and Chau 2006). The method employed in this study, however, does not measure suspended sediment load (SSL) which is indispensable for planning and management of water resource structures (Alizadeh et al. 2017; Olyaie et al. 2015). Nonetheless, it can predict the origin of recharge water and the source of water quality parameters. Acceptable forecasts of daily suspended sediment concentration of up to 3 days in advance can be predicted accurately using the proposed single-wavelet ANN model which indicates superiority of the ensemble model (Alizadeh et al. 2017).

For the record, water is an essential natural resource for sustainability of life among all organisms, plants and higherorder animals including man and has been established that human beings may live for several weeks without food but this is not possible without water which is a critical component for replenishing body fluids lost through physiological 
processes (Igwe et al. 2015). Moreover, water is important for removal of toxins in the body system (Olyaie et al. 2015; Igwe et al. 2015). Accordingly, the lack of adequate supply of clean water is a serious challenge in developing countries especially in Sub-Saharan Africa. Proper wastewater management plays a crucial role in achieving good water status and the potential restoration of water resources (Wilk et al. 2019).

The natural quality of water can vary from one rock type to another and also within aquifers along groundwater flow paths, and differs markedly from various geological environments (Oyem et al. 2014). Previously, we carried out a study on the quality of borehole water in Kakamega County which focused mainly on heavy metals and other physicochemical parameters. This study, however; is different because it focuses on the quality of water in River Molo-no heavy metals are discussed in the present study. Additionally, this work is carried out in a different geographical region with no mining history, and thus overlap of data is judiciously minimized. Molo river lies within the floor of the Kenyan rift system believed to contain soils rich in various minerals; therefore, the investigation of its water quality will benefit the residents of Nakuru County who rely heavily on the Molo river water for their domestic, irrigation and industrial processes. It is important to note that there are many flower farms that have mushroomed along the river that may hurt the water quality of the water. Therefore, the health concern of the water is necessary for public health policy formulation. Technically, this study will not invest in the study of heavy metals and hazardous organics but will focus primarily on physicochemical parameters which can easily be used to determine the water quality index.

The main source of drinking water in Africa, Latin America and Asia are primarily streams, rivers, boreholes and wells which are largely untreated, and may be associated with various health risks. Natural water is contaminated by a wide range of organic, inorganic and biological pollutants (Chinedu et al. 2011). The most notorious poisonous heavy metal is lead which is highly toxic even at relatively low concentrations (Chinedu et al. 2011; Alemu et al. 2017). Moreover, metals possess accumulative effect at even at low level in drinking water. Food chain transfer may also increase toxicological effect in humans (Alemu et al. (2017)). In other cases, the pollutant is not toxic but its presence results in conditions which are detrimental to the quality of water (Erikson et al. 2005). For example, pH must be stable within a range favorable to the particular organisms involved. The increased application of commercial fertilizer and widespread use of variety of organo-pesticides, insecticides, herbicides and weed killers in agricultural practices precipitate grave pollution problems from land drainage (Nag and Suchetana 2016). This type of agricultural pollution has severe impact on water pollution because most of pollutants are resistant to natural degradation (Erikson et al. 2005; Nag and Suchetana 2016).

Although concentrations of the pollutants are rather low, many of these compounds are toxic to human or animal life; some of them are carcinogenic or have serious ecological health implications. Inadequate infrastructure for effective treatment and distribution of water results to high mortality rate associated with waterborne diseases in developing countries (Blanton et al. 2015). The quality of water influences the health status of any population; hence, assessment of physical-chemical properties including trace elements content is necessary for public health monitoring. The knowledge of hydrochemistry of surface water is important in assessing the quality of water especially in rural areas where people use water for both domestic and agricultural purposes.

The primary focus of this study is to undertake a comprehensive evaluation of the water quality of river Molo for purposes of drawing a road map for water quality monitoring and public health safety in Nakuru and Baringo Counties. Over the years, the quality of river Molo has been deteriorating because of mushrooming of hospitality industries, flower farms and oil spills due to regular motor accidents in the notorious Nakuru-Salgaa highway. The Mau section of the river is rich in agricultural practices, and this may contribute to elevated levels of nitrates, sulfates and phosphates. Anthropogenic sources due to volcanic rich soils are another source of elemental pollution of the river occasioned by surface runoffs during the rainy season and water drainages from car washing industries. This study, therefore, is one of the first in-depth investigations of water quality resource in the river Molo water basin. Accordingly, this work will examine in detail the physicochemical characteristics, \%sodium, magnesium hazard (MH), permeability index (PI) and hydrogeochemical facies with the aim of qualifying the water for domestic use, irrigation and industrial purposes.

\section{The study area}

This research focused on the upper part of river Molo which has its source at Mau complex and empties its water into Lake Baringo. Around Molo town, the river receives domestic discharges and waste effluent from flower farms which contaminate the water hence such water may not be fit for domestic use (cf. Fig. 1). The study area is located between latitude $00^{\circ} 11.99232^{\prime} \mathrm{S}$ and $00^{\circ} 15.530^{\prime} \mathrm{S}$, longitude $035^{\circ}$ $44.044^{\prime} \mathrm{E}$ and $035^{\circ} 51.846^{\prime} \mathrm{E}$. This section of river Molo basin lies at an altitude of between 1908 and $2437 \mathrm{~m}$ above sea level (m.a.s.l). The sampling points were Molo town (S1), Kibunja (S2), Salgaa main River (S3), Salgaa tributary 1 (S4), Salgaa tributary 2 (S5) and Salgaa tributary 3 (S6) as shown in Fig. 2. 
Fig. 1 Children drawing water from a section of river Molo

Fig. 2 Location of the sampling points
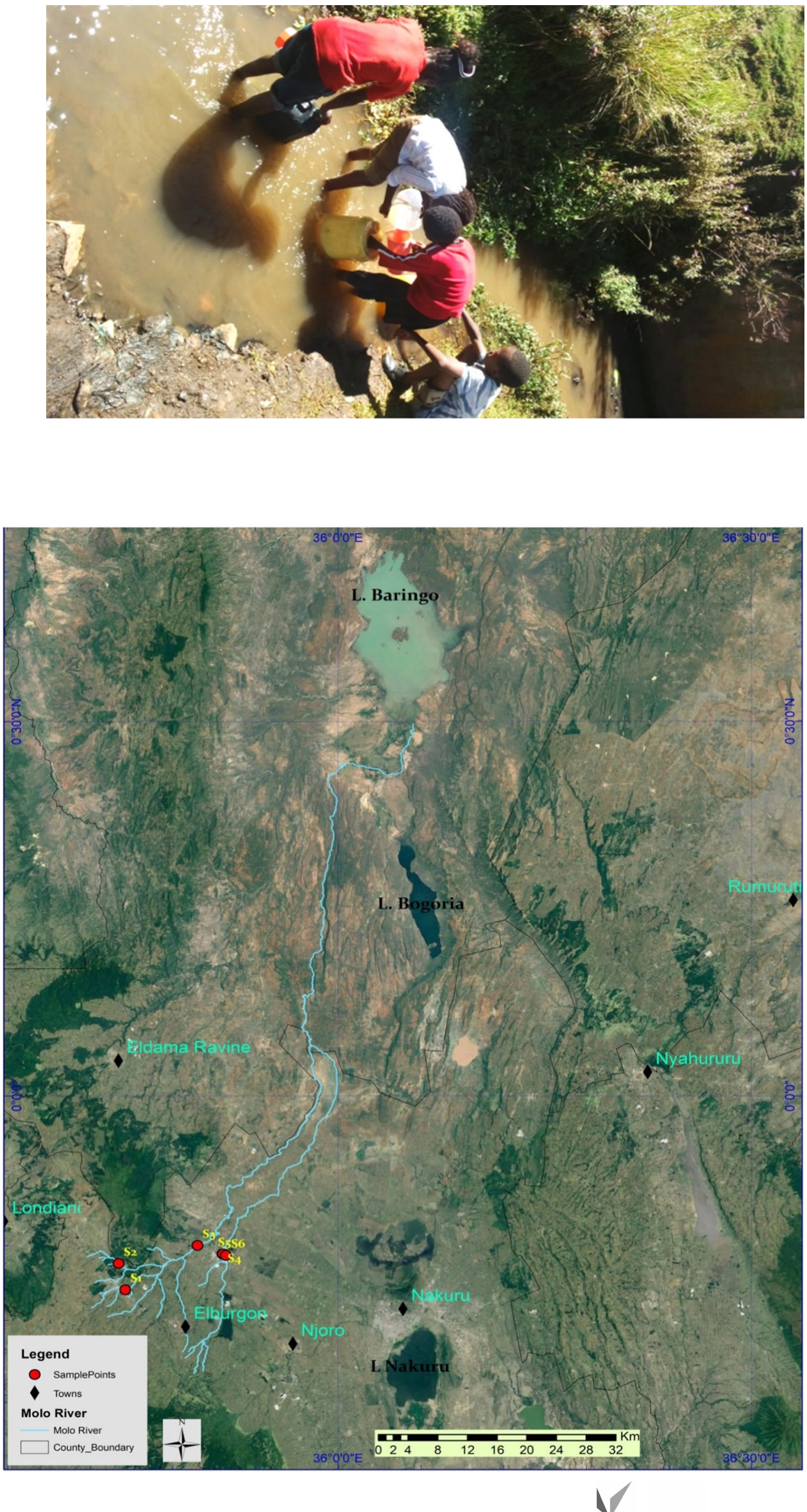

Springer 
At Salgaa town (Molo River), the main pollutants are discharges from flower farms, oil spills from heavy commercial vehicles which transport oil products to East African countries including South Sudan. The car washing industry also contributes significantly to water pollution in this part of the river. Essentially, micro-pollutants in the environment are precursors for serious public health problems particularly in highly populated regions, where water resources are used for drinking and irrigation purposes and as wastewater sinks (Wilk et al. 2019).

\section{Materials and methods}

The reagents used in this study were of analytical grade $(\geq 99.9 \%)$ and were procured from Sigma-Aldrich Inc. (St. Louis, Missouri, USA) through Kobian Company Ltd., Kenya. Water samples were collected in duplicate from six sampling points using 2-L sterilized plastic containers. The $\mathrm{pH}$ of water samples for essential metal analysis was reduced to less than $2 \mathrm{pH}$ units by adding $1 \mathrm{~mL}$ of concentrated nitric acid.

The quality of drinking water is a powerful environmental determinant of health which must be noted as a basic human need (Oyem et al. 2014). The pH, temperature, TDS and electrical conductivity were determined in situ using by a portable multi-parameter meter, Temp/pH/TDS/EC meter (model MI 1399). The meter is cost effective, easy to use and water resistant. Due to its stability, the meter reproduced the results reported in this study. The samples were transported in a cooler box to the laboratory where they were refrigerated at $4{ }^{\circ} \mathrm{C}$ prior to analysis. For determination of sodium and potassium, samples and standard solutions were digested for $30 \mathrm{~min}$ on a hot plate in fume hood after which they were filtered and transferred to $100-\mathrm{mL}$ volumetric flask. Prior to the analysis of potassium, sodium, magnesium and calcium in the water sample, $5 \mathrm{~mL}$ of $71 \% \mathrm{HNO}_{3}$ (nitric acid) was used to digest $100 \mathrm{~mL}$ of the samples for $30 \mathrm{~min}$ on hot plate in a fume hood. The anions were determined using spectrophotometer (model DR 3000) with robust industrial specifications-analysis wavelength from $\sim 300$ to $1000 \mathrm{~nm}$, accuracy within $\pm 1 \mathrm{~nm}, 9 \mathrm{~nm}$ bandwidth and less than $0.1 \%$ transmittance of stray light. SPADNS, turbidimetric, ascorbic acid, colorimetric, argentometric and potentiometric methods were used to determine the concentrations of fluorides, sulfates, phosphates, nitrates, chlorides, carbonates and bicarbonates, respectively. Sodium, potassium, calcium and magnesium were determined by flame emission photometry. In order to categorize water samples into various classifications, the Piper and Durov diagram were generated using AquaChem ver. 3.7.42.

\section{Results and discussion}

\section{pH, temperature, electrical conductivity and total dissolved solids}

The physical-chemical parameters from six sampling points along Molo river are given in Table 1.

The $\mathrm{pH}$ values ranged from 7.9 to 9.66. Sampling points $\mathrm{S} 3, \mathrm{~S} 4$ and $\mathrm{S} 5$ recorded $\mathrm{pH}$ values which are above the World Health Organization (WHO) recommendation for both drinking and irrigation water (6.5-8.5). The temperature readings ranged from 14.0 to $31.5^{\circ} \mathrm{C}$. For aesthetic purpose, drinking water should have a temperature which
Table 1 Analytical data for the surface water samples from the study area

\begin{tabular}{llllllll}
\hline $\begin{array}{l}\text { Physicochemical param- } \\
\text { eters, anions and cations }\end{array}$ & \multicolumn{2}{l}{ Sampling points } & & & & \\
\cline { 2 - 8 } & $\mathrm{S} 1$ & $\mathrm{~S} 2$ & $\mathrm{~S} 3$ & $\mathrm{~S} 4$ & $\mathrm{~S} 5$ & $\mathrm{~S} 6$ & WHO standards \\
\hline $\mathrm{pH}$ & 8.02 & 8.22 & 8.60 & 9.66 & 8.76 & 7.9 & $6.5-8.0$ \\
Temperature $\left({ }^{\circ} \mathrm{C}\right)$ & 14.02 & 14.2 & 17.1 & 27.5 & 27.5 & 31.5 & 15 \\
Conductivity $(\mu \mathrm{S} / \mathrm{cm})$ & 260 & 165 & 181 & 1354 & 1637 & 567 & 1500 \\
TDS $(\mathrm{mg} / \mathrm{L})$ & 130 & 79 & 90 & 678 & 823 & 274 & 1000 \\
Fluorides $(\mathrm{mg} / \mathrm{L})$ & $\mathrm{nd}$ & $\mathrm{nd}$ & $\mathrm{nd}$ & 3.28 & 2.76 & $\mathrm{nd}$ & 1.5 \\
Sulfates $(\mathrm{mg} / \mathrm{L})$ & 6.45 & 5.53 & 4.97 & 85.66 & 60.32 & 26.39 & 400 \\
Phosphates $(\mathrm{mg} / \mathrm{L})$ & 0.44 & 0.13 & 0.27 & 4.55 & 11.06 & 0.25 & 0.5 \\
Nitrates $(\mathrm{mg} / \mathrm{L})$ & 10.66 & 3.08 & 6.16 & 4.32 & 2.09 & 1.73 & 45 \\
Chloride $(\mathrm{mg} / \mathrm{L})$ & $\mathrm{nd}$ & $\mathrm{nd}$ & $\mathrm{nd}$ & 38.5 & 69.4 & $\mathrm{nd}$ & 250 \\
Carbonates $(\mathrm{mg} / \mathrm{L}$ & 20 & 26 & 18 & 120 & 148 & 84 & $\mathrm{NS}$ \\
Bicarbonates $(\mathrm{mg} / \mathrm{L})$ & 60 & 58 & 54 & 230 & 384 & 182 & 300 \\
Sodium $(\mathrm{mg} / \mathrm{L})$ & 104.1 & 19.0 & 100.0 & 1220.0 & 1800.0 & 146 & 200 \\
Potassium $(\mathrm{mg} / \mathrm{L})$ & 10.6 & 15.8 & 8.9 & 90.2 & 121.0 & 60.6 & $\mathrm{NS}$ \\
Calcium $(\mathrm{mg} / \mathrm{L})$ & 17.7 & 13.4 & 10.2 & 77.4 & 93 & 38 & 200 \\
Magnesium $(\mathrm{mg} / \mathrm{L})$ & 14.0 & 9.0 & 6.0 & 6.8 & 106.8 & 4.8 & 100 \\
\hline
\end{tabular}


is equal to or less than $15{ }^{\circ} \mathrm{C}$. Temperature above $15{ }^{\circ} \mathrm{C}$ enhances the growth of nuisance organisms and may lead to increase in problems related to odor, taste, color and corrosion. Cattle typically prefer drinking water at temperatures between 4.4 and $18.3{ }^{\circ} \mathrm{C}$. When the temperature is more than $27{ }^{\circ} \mathrm{C}$, water and feed intake rates often decrease, affecting animal productivity (Chinedu et al. 2011). The electrical conductivity values ranged from 260 to $1637 \mu \mathrm{s} / \mathrm{cm}$. Water ability to conduct electric current is referred to as electrical conductivity, and serves as parameter to assess the purity of water depending on the presence of ions, their total concentration, mobility, valence, relative concentrations and the temperature (Oyem et al. 2014). The electrical conductivity values at sampling points $\mathrm{S} 4$ and S5 were above the WHO guidelines for domestic water $(1000 \mu \mathrm{s} / \mathrm{cm})$. This might be attributed to dissolved bicarbonate, sodium, sulfate, magnesium and calcium salts in addition to other anions such chlorides and fluorides (Table 1). Electrical conductivity indicates the amount of total dissolved ions in water (Yilmaz and Koç (2014)). Generally, this is a measure of the dissolved ionic components in water and hence the electrical behavior of the water (Oyem et al. 2014). Clearly, the levels of sodium ions in this two sampling points are significantly high (1220 and $1800 \mathrm{mg} / \mathrm{L}$, respectively). Run off from agricultural farms may have resulted in high electrical conductivity. If the conductivity values are less than $1000 \mu \mathrm{s} / \mathrm{cm}$, then the water is safe for drinking. If the value is between 1000 and $2999 \mu \mathrm{s} / \mathrm{cm}$, then it may cause mild diarrhea, whereas above $3000 \mu \mathrm{s} / \mathrm{cm}$, domestic animals may detest drinking the water considered a precursor for acute diarrhea (WHO 2011). Total dissolved solids (TDS) refer to the sum of all components dissolved in water which include $\mathrm{K}^{+}, \mathrm{Na}^{+}$, $\mathrm{Ca}^{2+}, \mathrm{Mg}^{2+}, \mathrm{SO}_{4}{ }^{2-}, \mathrm{Cl}^{-}, \mathrm{PO}_{4}{ }^{3-}$ and $\mathrm{H}_{4} \mathrm{SiO}_{4}{ }^{2-}$ (WHO 2011). The TDS in the sampled water ranged from 79 to $823 \mathrm{mg} / \mathrm{L}$. Drinking water is significantly affected if the TDS value is $\geq 1000 \mathrm{mg} / \mathrm{L}$ (WHO 2011). To date, there is no health-based guideline for TDS in Kenya; however, $1000 \mathrm{mg} / \mathrm{L}$ is recommended for humans according to the WHO (2011). Water with high dissolved solids is known to cause impairment of physiological processes in the human body, and may lead to gastrointestinal irritation especially for people suffering from kidney problems (Ramesh and Bhuvana 2012). They are also not desired for industrial use as they form scales, accelerate corrosion, precipitate foaming in boilers and may interfere with the taste and color of finished products (Sarda and Sadgir 2015).

\section{Major anions}

The concentration of fluorides in sample collection sites S4 and S5 ranged between 2.76 and $3.28 \mathrm{mg} / \mathrm{L}$, respectively. These values were considerably above the WHO recommended guideline for drinking water set at $1.5 \mathrm{mg} / \mathrm{L}$ (WHO
2011). Drinking water rich in fluorides may lead to dental fluorosis and the worst case scenario, skeletal problems (Shruthi and Anil 2018). This was evident from people living around Salgaa area and the larger Nakuru County. Skeletal fluorosis may manifest itself when one drinks water containing 3-6 mg/L of fluoride (Shruthi and Anil (2018); Sellami et al. 2019). The data predict that people around Salgaa area and especially on the banks or Molo river area are at risk of skeletal fluorosis.

In the present study, the levels of sulfates ranged from 4.97 to $85.66 \mathrm{mg} / \mathrm{L}$. These levels were found to be below the WHO limits of $400 \mathrm{mg} / \mathrm{L}$ (WHO 2011; Shruthi and Anil 2018). Location $S 4$ which was believed to receive effluents from a nearby flower farm and domestic wastes recorded the highest concentration of sulfates (Table 1). Drinking water with sulfate concentration above $200 \mathrm{mg} / \mathrm{L}$ may also lead gastrointestinal irritation and bowel discomfort (WHO 2011; Sharma and Bhattacharya 2017).

The levels of phosphates in the present study ranged from 0.13 to $11.06 \mathrm{mg} / \mathrm{L}$. The phosphate levels at sample locations S4 and S5 were above the WHO permissible limit of $0.5 \mathrm{mg} / \mathrm{L}$ (WHO 2011; Nieder et al. 2018). The source of phosphates at these two points may be attributed to excess use of fertilizers in the farms and possibly anthropogenic sources such as phosphate rocks (gypsum) considered abundant in the Kenyan Rift system. It is well-established in literature that phosphates are not very mobile in soils and are only moderately soluble but their transportation through surface runoff and soil erosion can significantly increase their solubility in surface waters (Nieder et al. 2018). Although phosphate is not harmful to humans, anthropogenic, or man-made, inputs of phosphorus are well-known to have a significant impact on natural ecosystems, and can damage the health of rivers and lakes as a result of massive growth of algae (algal bloom) which cloud the water and reduce the sunlight available to other plants (Nieder et al. 2018). When the algae die, the bacteria that biodegrade the algae use up dissolved oxygen in the water and hence depriving aquatic systems of oxygen leading to suffocation of aquatic life (Sarda and Sadgir 2015).

The amount of nitrates in the water samples ranged from 1.73 to $10.66 \mathrm{mg} / \mathrm{L}$ which are below the $45 \mathrm{mg} / \mathrm{L}$ recommended by WHO for safe drinking water (Yilmaz and Koç 2014; WHO 2011). The main sources of nitrate in water are animal and human waste, industrial effluent and use of chemicals, fertilizers and silage through drainage systems (Shruthi and Anil 2018). Nitrate levels above $40 \mathrm{mg} / \mathrm{L}$ in water causes "blue baby syndrome" or "methamoglobinemia" in children (Sellami et al. 2019). Interestingly, excess nitrates in water cannot be removed by boiling (Sharma and Bhattacharya 2017).

Chlorides were recorded at S4 and S5 with concentrations ranging from 38.5 to $69.4 \mathrm{mg} / \mathrm{L}$, respectively. These 
values are considerably below the WHO limit of $250 \mathrm{mg} / \mathrm{L}$ and therefore do not pose any immediate health risk to consumers. In portable water, the salty taste is as a result of chloride concentration above $100 \mathrm{mg} / \mathrm{L}$ and has laxative effect for people not accustomed to such waters (WHO 2011). High chloride concentration in water may be an indicator of pollution by sewage or irrigation leachates (Sarda and Sadgir 2015). The carbonates and bicarbonates in this study ranged from 18 to 84 and 54 to $182 \mathrm{mg} / \mathrm{L}$, respectively (cf. Table 1). The content of bicarbonates has no known adverse health effect and all the surface water except $\mathrm{S} 6$ fall within the desirable limit of $300 \mathrm{mg} / \mathrm{L}$ (WHO 2011; Murakami et al. 2015).

\section{Major cations}

The average concentration of sodium in this study was $564.85 \mathrm{mg} / \mathrm{L}$ which is approximately 3 times the WHO permissible limit of $200 \mathrm{mg} / \mathrm{L}$. S4 and S5 recorded the highest concentration of sodium. These elevated sodium levels may be attributed to sewage discharge, domestic effluents and leachates from sodium containing rocks, and possible recharge water from underground systems which may be rich in brine. Fractures within the river system may lead to mineralized regimes that produce mineral veins and saline intrusion into the river which in turn result in elevated major ions in the river water. Studies have shown that high intake of sodium in drinking water may lead to hypertension in pregnant women (Alsulaili et al. 2015), and children whose kidneys are not mature enough to excrete excess sodium (Rahman et al. 2016). Infants with severe gastrointestinal infections can suffer from fluid loss, leading to dehydration and increased sodium levels in the plasma (hypernatraemia) and serious neurological damage occasioned by high intake of sodium (Rahman et al. 2016; Scheelbeek et al. 2016). The levels of potassium in this study ranged from 10.6 to $121 \mathrm{mg} / \mathrm{L}$. Although there is no recommended limit of potassium in water, increased exposure may result in significant health effects in people with kidney disease or other conditions, such as heart disease, coronary artery disease, hypertension, diabetes, adrenal insufficiency, older individuals who have reduced physiological reserves in their renal function and/or individuals who are under medications that interfere with the normal handling of potassium in the body (Scheelbeek et al. 2016; Leurs et al. 2010). The level of calcium and magnesium reported in this work ranged from 10.2 to 93 and 4.8 to $106.8 \mathrm{mg} / \mathrm{L}$, respectively. Sampling point $\mathrm{S} 5$ had magnesium levels above the WHO limit of $100 \mathrm{mg} / \mathrm{L}$ (WHO 2011; Leurs et al. 2010). Calcium is important for good health, and levels between 20 and $30 \mathrm{mg} / \mathrm{L}$ are desirable in drinking water (Leurs et al. 2010).

\section{Hydrogeochemical facies}

There has been an exponential increase in the need for the suitable evaluation of river water quality with the aim of safeguard public health and protecting water resources (Yilmaz and Koç 2014); therefore, model processes such as the use of Piper plots and Durov plots have become important. The Piper diagrams are useful for demonstrating large amounts of data and defining major trends ion concentrations (Al-Bassam and Khalil 2012). In order to overcome the limitations of traditional data assessment which can only use a point value instead of an interval for grading standards, models such as AquaChem have become indispensable (Wilk et al. 2019). The Piper plot was used to determine the suitability of water for drinking purposes (Christine et al. 2018). This plot presents two triangles: one for cations and the other for anions. The anions and cations field are combined to show a single point in a diamond-shaped field from which the inference is drawn from hydrogeochemical facies concept. The geochemical evolution of groundwater can be understood by plotting the milliequivalent (meq) concentrations of major cations and anions in a Piper trilinear diagram (Christine et al. 2018) (cf. Fig. 3). The Piper diagram (Fig. 3) for Molo river was created using analytical data obtained from hydrogeochemical data. The piper diagram can predict water types based on the anions into three: the sulfate type, bicarbonate and chloride type. The bicarbonate type is considered to be suitable for both drinking and agriculture practices, while the sulfate type is unsuitable for irrigation (Nagaraju et al. 2016; Ziani et al. 2017). All the water samples fall under bicarbonate or freshwater zone.

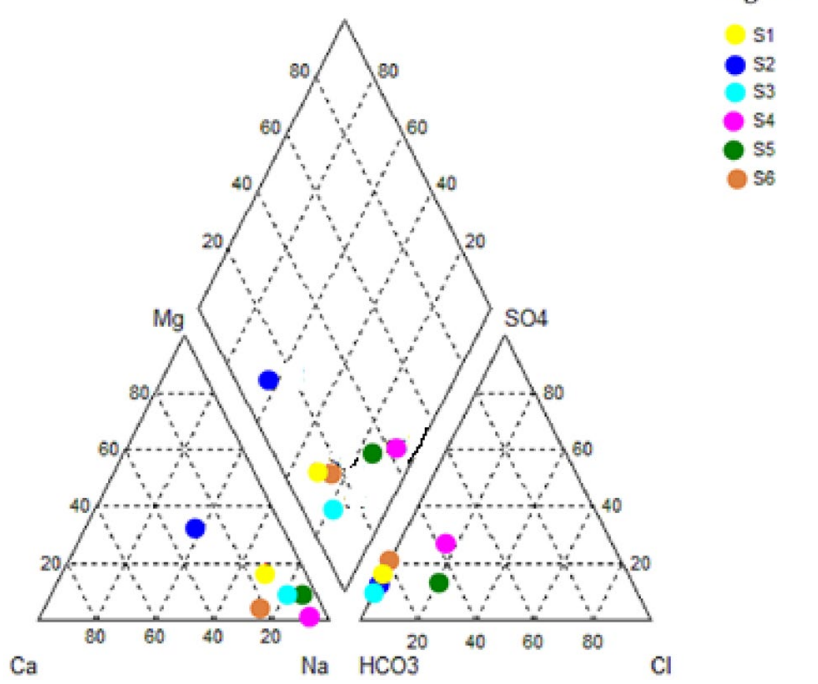

Fig. 3 Piper plot for this study 
The sampling points can be classified into five water types based on cations and anions as follows: $\mathrm{Na}-\mathrm{Mg}-\mathrm{Ca}-\mathrm{HCO}_{3}$ type (S1), $\mathrm{Na}-\mathrm{Ca}-\mathrm{Mg}-\mathrm{HCO}_{3}-\mathrm{CO}_{3}(\mathrm{~S} 2), \mathrm{Na}-\mathrm{HCO}_{3}(\mathrm{~S} 3)$, $\mathrm{Na}(\mathrm{S} 4$ and $\mathrm{S} 5)$ and $\mathrm{Na}-\mathrm{Ca}-\mathrm{HCO}_{3}-\mathrm{CO}_{3}$ (S6) water types (Fig. 3). It is remarkable that the total hydrochemistry is dominated by alkalis with sodium being the main species.

The ion concentration of sample of all the sampling points is also shown by Durov diagram which is a modification of the piper diagram (Anindita and Nag 2018). The Durov diagram was employed in order to understand the hydrochemical process controlling the ground water system (Christine et al. 2018). Two triangles are used for plotting major ions as percentage of milliequivalent. The square grid which lies perpendicular to the third axis in each triangle is used to project the data points from two triangles (Al-Bassam and Khalil 2012; Christine et al. 2018). From the Durov diagram (Fig. 4), it was found that the sodium ion and the carbonates were high in all the samples.

More recently, soft computing techniques have been used in hydrological and environmental modeling because accurate and reliable prediction models are necessary for planning and managing water resource structures (Wang et al. 2014).

\section{Water quality with respect to irrigation}

In this study, water quality with respect to agricultural/ irrigation is evaluated using the following methods: Sodium adsorption ratio (SAR), sodium percent, magnesium hazard and permeability index (PI). Sodium adsorption ratio (SAR) is an important chemical parameter which

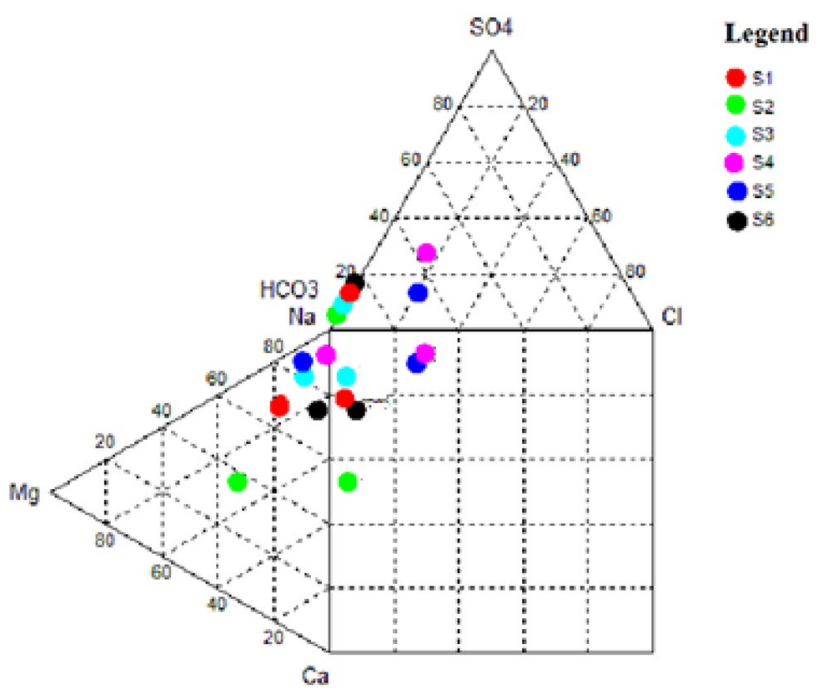

Fig. 4 Durov plot for water samples from River Molo is used to judge the degree of suitability of water for irrigation (Ali and Ali 2018). The SAR parameter is obtained using Eq. 1, where ionic concentrations are in the units of $\mathrm{meq} / \mathrm{L}$.

$\mathrm{SAR}=\frac{\mathrm{Na}^{+}}{\frac{\sqrt{\mathrm{Ca}^{2+}+\mathrm{Mg}^{2+}}}{2}}$

Excess sodium in water causes adverse effect of changing soil properties and thus reducing soil permeability (Nagaraju et al. 2014). SAR indicates the degree to which irrigation water enters cation-exchange reaction in soil. Sodium replacing adsorbed calcium and magnesium is a hazard as it damages the soil structure mainly permeability which results in poor internal drainage (Ziani et al. 2017; Wang et al. 2015). Water in SI, S2, S3 and S6 can be used for irrigation without serious negative effects because their SAR values are less than 10, while that of S4 and S5 have high SAR above 26 (Table 2). Water in S4 recorded the highest SAR of 35.2 which can make the soil compact and impervious and hence cannot be used for irrigation in all the water types.

\section{Sodium percent}

High sodium percent reduces soil permeability and consequently plant growth; therefore, soil may require special treatment such as addition of gypsum to increase permeability. Ideally, the $\% \mathrm{Na}^{+}$should not exceed 60 in water recommended for irrigation (Wakeel 2013). Sodium percent can be computed using Eq. 2. Concentrations of species are in $\mathrm{meq} / \mathrm{L}$.

$\% \mathrm{Na}^{+}=\frac{\left(\mathrm{Na}^{+}+\mathrm{K}^{+}\right)}{\left(\mathrm{Na}^{+}+\mathrm{K}^{+}+\mathrm{Mg}^{2+}+\mathrm{Ca}^{2+}\right)}$

From the results (Table 3), it is only S2 which had excellent water for irrigation. The other sampling points have high $\% \mathrm{Na}^{+}$(> $\left.60 \mathrm{meg} / \mathrm{L}\right)$, therefore unfit for irrigation.

Table 2 Classification of SAR for agricultural use in this study (Anindita and Nag 2018)

\begin{tabular}{lll}
\hline Water classes & $\begin{array}{l}\text { Sodium adsorption ratio } \\
\text { (SAR) }\end{array}$ & Sampling points \\
\hline Excellent & Up to 10 & S1, S2, S3 and S5 \\
Good & $10-18$ & - \\
Permissible & $18-26$ & - \\
Unacceptable & Above 26 & S4 and S6 \\
\hline
\end{tabular}


Table $3 \% \mathrm{Na}$ in the Molo river basin reported in this investigation

\begin{tabular}{ll}
\hline Sampling point & \% Sodium \\
\hline S1 & 70.2 \\
S2 & 46.6 \\
S3 & 82.0 \\
S4 & 92.6 \\
S5 & 85.2 \\
S6 & 77.5 \\
\hline
\end{tabular}

\section{Magnesium hazard (MH)}

Conventionally, $\mathrm{Ca}^{2+}$ and $\mathrm{Mg}^{2+}$ maintain a state of equilibrium in most waters. However, more $\mathrm{Mg}^{2+}$ in water adversely affects crop yield (Ali and Ali 2018; Wakeel 2013). Magnesium deteriorates soil structure especially when the water is sodium dominated and highly saline. A high level of $\mathrm{Mg}^{2+}$ is normally due to the presence of exchangeable $\mathrm{Na}^{+}$in irrigated soil. In this study, the magnesium hazard was computed using Eq. 3 .

$$
\mathrm{MH}=\frac{\left(\mathrm{Mg}^{2+}\right)}{\left(\mathrm{Mg}^{2+}+\mathrm{Ca}^{2+}\right)}
$$

All ion species applied in Eq. 3 are expressed in meq/L. A magnesium ratio of more than $50 \mathrm{me} / \mathrm{L}$ is considered to be harmful; therefore, such waters are unsuitable for drinking and irrigation purposes. In this work, $\mathrm{MH}$ ranged between 12.6 and $65.4 \mathrm{me} / \mathrm{L}$. Water from sampling points S1, S2 and $\mathrm{S} 5$ had MH values greater than $50 \mathrm{me} / \mathrm{L}$ therefore not suitable for agricultural practices.

\section{Permeability index}

Soil permeability plays an important role in plant growth. Low permeability index values do not support plant growth. Permeability of soil is affected by calcium, magnesium, sodium and bicarbonate contents of irrigation water. Permeability index (PI) developed by Doneen (Nagaraju et al. 2014) is computed according to Eq. 4 . The ion concentrations in the equation are expressed in $\mathrm{meq} / \mathrm{L}$.

$\% \mathrm{Na}^{+}=\frac{\left(\mathrm{Na}^{+}+\sqrt{\mathrm{HCO}_{3}^{-}}\right)}{\left(\mathrm{Na}^{+}+\mathrm{Mg}^{2+}+\mathrm{Ca}^{2+}\right)} \times 100$

The permeability index calculated for $\mathrm{S} 1$ to $\mathrm{S} 6$ was 84.0 , 79.0, 98.2, 96.7, 88.09 and $93.46 \mathrm{me} / \mathrm{L}$, respectively. This suggests that the water has good permeability index.
Table 4 Categorization of drinking water based on physicochemical parameters (Qureshimatva et al. 2015)

\begin{tabular}{ll}
\hline Water Quality Index level & Water quality status \\
\hline $0-25$ & Excellent water quality \\
$26-50$ & Good water quality \\
$51-75$ & Poor water quality \\
$76-100$ & Very poor water quality \\
$>100$ & Unsuitable for drinking \\
\hline
\end{tabular}

\section{Water Quality Index (WQI)}

In addition to \% sodium and magnesium hazard, it is also recommended that water quality parameters be included in water quality index (WQI) analyses in order to give the true status of the quality of a water resource (Allan et al. 2015). Nonetheless, this study will not focus on this parameter but will review it as one of the alternatives for determining water quality for drinking and irrigation. The expression for computing WQI is given by Eq. 5 .

$\mathrm{WQI}=\frac{\sum q_{n} W_{n}}{\sum W_{n}}$

where $q_{n}$ is the quality rating of the $n$th water quality parameter, and $W_{n}$ is the unit weight of the $n$th water quality parameter. For instance, the quality rating for $q_{\mathrm{pH}}=100\left[\frac{9.66-7}{8.5-7}\right]=150$ for water sample collected at station 4 (S4). Applying a similar expression, we obtain a $q_{\mathrm{pH}}=68$ for water sample collected at station S1. This result is consistent with the results given in Table 3. Generally, WQI is an effective monitoring tool that provides useful information of water from various sources and often incorporates several water quality parameters to describe the state of the water resources and its potential application for drinking purposes (Olasoji et al. 2019; Allan et al. 2015). Various authors have developed a table as a guide for water quality (Table 4) (Olasoji et al. 2019; Qureshimatva et al. 2015).

Clearly, water quality index summarizes a number of water quality data as excellent, good, poor, bad etc. (Table 4). WQI gives the general public an idea of the possible water problems in a particular region and is among the most effective indicators on water quality trends for water quality management.

\section{The speciation of inorganic carbon}

The speciation of inorganic carbon into various species is reported in Fig. 5. Clearly as expected, carbonic acid $\left(\mathrm{H}_{2} \mathrm{CO}_{3}\right)$ exists entirely at $\mathrm{pH}$ less than 4 and decreases sharply as the $\mathrm{pH}$ increased. 


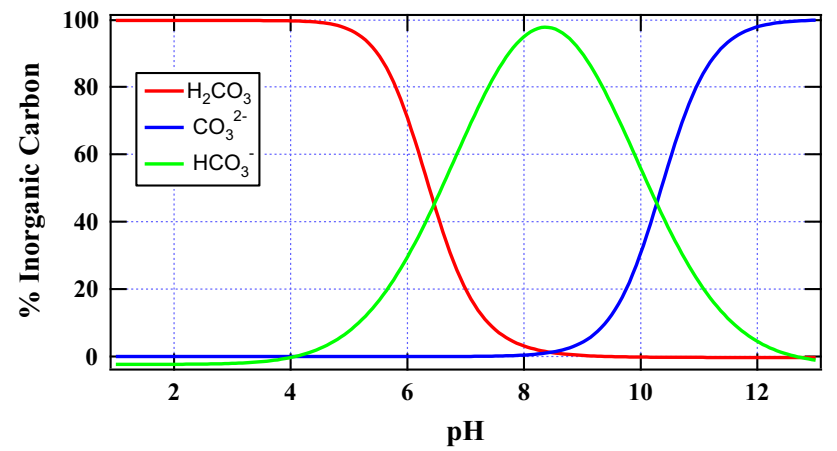

Fig. 5 Speciation of inorganic carbon into various forms

The bicarbonate $\left(\mathrm{HCO}_{3}^{-}\right)$form increases from $\mathrm{pH} 4$ and reaches a maximum at a $\mathrm{pH}$ of about 8.3. On the other hand, the carbonate $\left(\mathrm{CO}_{3}^{2-}\right)$ species exists from $\mathrm{pH} 8.0$ and reaches a maximum at a $\mathrm{pH} \geq 13.0$.

The rapid economic explosion, destruction of water towers and growth in agricultural practices, industrial and municipal development in any region lead to substantial accumulation of toxic waste and significant environmental impact imposed on the water environments (Chau 2005). Nonetheless, local authorities have stepped in to implement environmental restoration programs including assessing the cumulative impact of exploitation and restoration activities on the environment (Wang et al. 2014). The consumption of clean and safe drinking water has been linked to positive health outcomes; however most developing countries suffer from clean water supply due to the poor water supply infrastructure and inadequate supply of potable water (Olasoji et al. 2019).

\section{Conclusion}

This study has demonstrated that $\mathrm{pH}$ values were high indicating that water is alkaline possibly due to application of fertilizers in the nearby farms around the study area in addition to other anthropogenic sources. Fluoride, electrical conductivity, phosphates, sodium and potassium were above the World Health Organization permissible limit especially in S4 and S5. These elevated concentrations may serve as precursors for waterborne diseases including fluorosis and hypertension. The Piper and the Durov plots indicate that all the water samples fall under bicarbonate water zone, and the total hydrochemistry is dominated by alkalis mainly sodium. SAR in S4 was very high which makes the water in the river Molo basin unsuitable for irrigation as well as domestic use. Magnesium hazard was significantly high in S1 S2 and S5. Only S2 had good water for irrigation as predicted by a low $\% \mathrm{Na}^{+}$. This study as assessed that water in S1, S4, S5 and S6 may not be fit for drinking or irrigation.
Therefore, continuous evaluation of ground water quality is very important for public safety and environmental monitoring. Nonetheless, this work has provided a baseline for the categorization of hazardous chemicals potentially discharged into the river. This study recommends the use of more soft computing techniques such as artificial neural networks (ANNs) and adaptive neuro-fuzzy inference system (ANFIS) to compliment the AquaChem data and traditional testing methods in order to predict with accuracy the water quality of Molo river and thence formulate better research-based policies by local authorities and government agencies.

Acknowledgements The authors are thankful to the National Research Fund (NRF-Kenya) for funding this study. The directorate of Research and Division (R\&E) is appreciated for facilitating the disbursement of funds. Jeremiah Kipng'ok of Geothermal Development Company (GDC) is acknowledged for providing the training on AquaChem used to generate Durov and Piper plots reported in this study.

Open Access This article is licensed under a Creative Commons Attribution 4.0 International License, which permits use, sharing, adaptation, distribution and reproduction in any medium or format, as long as you give appropriate credit to the original author(s) and the source, provide a link to the Creative Commons licence, and indicate if changes were made. The images or other third party material in this article are included in the article's Creative Commons licence, unless indicated otherwise in a credit line to the material. If material is not included in the article's Creative Commons licence and your intended use is not permitted by statutory regulation or exceeds the permitted use, you will need to obtain permission directly from the copyright holder. To view a copy of this licence, visit http://creativecommons.org/licenses/by/4.0/.

\section{References}

Al-Bassam AM, Khalil AR (2012) DurovPwin: a new version to plot the expanded Durov diagram for hydro-chemical data analysis. Comput Geosci UK 42:1-6. https://doi.org/10.1016/j.cageo .2012 .02 .005

Alemu T, Mulugeta E, Tadese M (2017) Determination of physicochemical parameters of "Hora" natural mineral water and soil in Senkele Kebele, Oromia Region, Ethiopia. Cogent chem 3(1):1354800. https://doi.org/10.1080/23312009.2017.1354800

Ali SA, Ali U (2018) Hydrochemical characteristics and spatial analysis of groundwater quality in parts of Bundelkhand Massif, India. Appl Water Sci 8(1):39. https://doi.org/10.1007/s1320 1-018-0678-x

Alizadeh MJ, Nodoushan EJ, Kalarestaghi N, Chau K-W (2017) Toward multi-day-ahead forecasting of suspended sediment concentration using ensemble models. Environ Sci Pollut Res 24(36):28017-28025. https://doi.org/10.1007/s11356-017-0405-4

Allan T, Keulertz M, Woertz E (2015) The water-food-energy nexus: an introduction to nexus concepts and some conceptual and operational problems. Int J Water Resour D 31(3):301-311. https://doi. org/10.1080/07900627.2015.1029118

Alsulaili A, Al-Harbi M, Al-Tawari K (2015) Physical and chemical characteristics of drinking water quality in Kuwait: tap vs. bottled water. J Eng Res 3(1):2. https://doi.org/10.7603/s4063 2-015-0002-y 
Anindita K, Nag SK (2018) Assessment of groundwater quality in Kashipur Block, Purulia district. West Bengal Appl Water Sci 8(1):33. https://doi.org/10.1007/s13201-018-0675-0

Blanton E, Wilhelm N, O'Reilly C, Muhonja E, Karoki S, Ope M (2015) A rapid assessment of drinking water quality in informal settlements after a cholera outbreak in Nairobi, Kenya. J Water Health 13(3):714-725. https://doi.org/10.2166/wh.2014.1738

Chau KW (2005) Characterization of transboundary POP contamination in aquatic ecosystems of Pearl River delta. Mar Pollut Bull 51(8):960-965. https://doi.org/10.1016/j.marpolbul.2005.02.028

Chinedu SN, Nwinyi O, Oluwadamisi AY, Eze VN (2011) Assessment of water quality in Canaanland, Ota, Southwest Nigeria. Agric Biol J N Am 2(4):577-583. https://doi.org/10.5251/abjna 2011.2.4.577.583

Christine AA, Kibet JK, Kiprop AK, Were ML (2018) The assessment of bore-hole water quality of Kakamega County, Kenya. Appl Water Sci 8(1):47. https://doi.org/10.1007/s13201-018-0688-8

Erikson KM, Dorman DC, Lash LH, Aschner M (2005) Persistent alterations in biomarkers of oxidative stress resulting from combined in utero and neonatal manganese inhalation. Biol Trace Elem Res 104(2):151-163. https://doi.org/10.1385/bter:104:2:151

Igwe O, Adepehin EJ, Adepehin JO (2015) Integrated geochemical and microbiological approach to water quality assessment: case study of the Enyigba metallogenic province. Southeast Niger Environ Earth Sci 74(4):3251-3262. https://doi.org/10.1007/ s12665-015-4363-1

Leurs LJ, Schoutent LJ, Mons MM, Goldbohm RA, Van den Brandt PA (2010) Relationship between tap water hardness, magnesium, and calcium concentration and mortality due to ischemic heart disease or stroke in the Netherlands. Environ Health Persp 118(3):414 420. https://doi.org/10.1289/ehp.0900782

Murakami S, Got Y, Ito K, Hayasaka S, Kurihara S, Soga T, Tomita M, Fukuda S (2015) The consumption of bicarbonate-rich mineral water improves glycemic control. Evid Based Complement Altern Med 2015:10. https://doi.org/10.1155/2015/824395

Nag SK, Suchetana B (2016) Groundwater quality and its suitability for irrigation and domestic purposes: a study in rajnagar block, Birbhum district, West Bengal India. J Earth Sci Clim Change 7:337. https://doi.org/10.4172/2157-7617.1000337

Nagaraju A, Sharifi Z, Balaji E (2016) Statistical and analytical evaluation of groundwater quality of Tirupati area, Chittoor district, Andhra Pradesh, South India. J Geol Soc India 88(2):222-234. https://doi.org/10.1007/s12594-016-0481-y

Nagaraju A, Sunil KK, Thejaswi A (2014) Assessment of groundwater quality for irrigation: a case study from Bandalamottu lead mining area, Guntur District, Andhra Pradesh, South India. Appl Water Sci 4(4):385-396. https://doi.org/10.1007/s13201-014-0154-1

Nieder R, Benbi DK, Reichl FX (2018) Reactive water-soluble forms of nitrogen and phosphorus and their impacts on environment and human health. Soil Compon Hum Health. https://doi. org/10.1007/978-94-024-1222-2_5

Olasoji SO, Oyewole NO, Abiola B, Edokpayi JN (2019) Water quality assessment of surface and groundwater sources using a Water Quality Index method: a case study of a peri-urban town in Southwest, Nigeria. Environments 6(2):23. https://doi.org/10.3390/envir onments6020023

Olyaie E, Banejad H, Chau K-W, Melesse AM (2015) A comparison of various artificial intelligence approaches performance for estimating suspended sediment load of river systems: a case study in United States. Environ Monit Assess 187(4):189. https://doi. org/10.1007/s10661-015-4381-1

Oyem HH, Oyem IM, Ezeweali D (2014) Temperature, pH, electrical conductivity, total dissolved solids and chemical oxygen demand of groundwater in Boji-BojiAgbor/Owa Area and immediate suburbs. Res J Environ Sci 8:444-450. https://doi.org/10.3923/ rjes.2014.444.450
Qureshimatva UM, Maurya RR, Gamit SB, Patel RD, Solanki HA (2015) Determination of physico-chemical parameters and Water Quality Index (WQI) of Chandlodia Lake, Ahmedabad, Gujarat, India. J Environ Anal Toxicol 5:288. https://doi.org/10.4172/21610525.1000288

Rahman A, Hashem A, Nur-A-Tomal S (2016) Potable water quality monitoring of primary schools in Magura district, Bangladesh: children's health risk assessment. Environ Monit Assess 188(12):680. https://doi.org/10.1007/s10661-016-5692-6

Ramesh K, Bhuvana JP (2012) Contamination of groundwater due to solid waste disposal and textile effluent in and around Erode City, Tamil Nadu. Int J Res Chem Environ 3:262-271

Sarda P, Sadgir P (2015) Assessment of multi parameters of water quality in surface water bodies-a review. Int J Res Appl Sci Eng Technol 3(8):331-336

Scheelbeek PF, Khan AE, Mojumder S, Elliott P, Vineis P (2016) Drinking water sodium and elevated blood pressure of healthy pregnant women in salinity-affected coastal areas. Hypertension 68(2):464-470. https://doi.org/10.1161/hypertensionaha .116 .07743

Sellami M, Riahi H, Maatallah K, Ferjani H, Bouaziz MC, Ladeb MF (2019) Skeletal fluorosis: don't miss the diagnosis! Skeletal Radiol. https://doi.org/10.1007/s00256-019-03302-0

Sharma S, Bhattacharya A (2017) Drinking water contamination and treatment techniques. Appl Water Sci 7(3):1043-1067. https://doi. org/10.1007/s13201-016-0455-7

Shruthi MN, Anil NS (2018) A comparative study of dental fluorosis and non-skeletal manifestations of fluorosis in areas with different water fluoride concentrations in rural Kolar. J Family Med Prim Care 7(6):1222-1228. https://doi.org/10.4103/jfmpc.jfmpc_72_18

WHO (2011) Guidelines for drinking water quality, 4th ed. WHO, Geneva. https://www.who.int/water_sanitation_health/publicatio ns/2011/dwq_guidelines/en/. Accessed 20 Aug 2018

Wakeel A (2013) Potassium-sodium interactions in soil and plant under saline-sodic conditions. J Plant Nutr Soil Sc 176(3):344354. https://doi.org/10.1002/jpln.201200417

Wang W-C, Xu D, Chau K-W, Lei G-J (2014) Assessment of river water quality based on theory of variable fuzzy sets and fuzzy binary comparison method. Water Resour Manag 28(12):41834200. https://doi.org/10.1007/s11269-014-0738-4

Wang D, Su Y, Zhou Q, Chen Z (2015) Advances in research on crop identification using SAR. Paper presented at the 2015 fourth international conference on agro-geoinformatics (agro-geoinformatics). https://doi.org/10.1109/Agro-Geoinformatics.2015.7248111b

Wilk BK, Fudala-Ksiazek S, Szopińska M, Luczkiewicz A (2019) Landfill leachates and wastewater of maritime origin as possible sources of endocrine disruptors in municipal wastewater. Environ Sci Pollut Res 26(25):25690-25701. https://doi.org/10.1007/ s11356-019-05566-4

Wu CL, Chau KW (2006) Mathematical model of water quality rehabilitation with rainwater utilisation: a case study at Haigang. Int J Environ Pollut 28(3-4):534-545. https://doi.org/10.1504/ IJEP.2006.011227

Yilmaz E, Koç C (2014) Physically and chemically evaluation for the water quality criteria in a farm on Akcay. J Water Resource Prot 6:63-67. https://doi.org/10.4236/jwarp.2014.62010

Ziani D, Abderrahmane B, Boumazbeur A, Benaabidate L (2017) Water quality assessment for drinking and irrigation using major ions chemistry in the semiarid region: case of Djacer Spring, Algeria. J Asian Earth Sci 10:9-21. https://doi.org/10.3923/ ajes.2017.9.21

Publisher's Note Springer Nature remains neutral with regard to jurisdictional claims in published maps and institutional affiliations. 